\title{
A STUDY ON THE RELATION BETWEEN CONSOLIDATION COEFFICIENT AND PLASTICITY INDEX OF FINE-GRADED SOILS
}

\author{
Assist. Prof. Dr. Kaveh DEHGHANIAN \\ İstanbul Aydın University \\ Engineering Faculty, Civil Engineering Department \\ kavehdehghanian@aydin.com \\ https:/orcid.org/0000-0002-6372-4984 \\ Emrah ÇALTILI \\ İstanbul Aydın University \\ Engineering Faculty, Civil Engineering Department \\ emrahcaltili@aydin.edu.tr \\ https://orcid.org/0000-0002-8411-3250
}

\begin{abstract}
Consolidation coefficient $\left(\mathrm{C}_{\mathrm{v}}\right)$ is one of the key parameters in calculation of soil settlement rate. This parameter can be determined using one-Dimensional consolidation test. Prediction of $\mathrm{C}_{\mathrm{v}}$ in fine-graded soils with different Liquid Limit (LL) and Plasticity Index (PI) is also substantial to have a better understanding of soil behavior. In the present study, two fine-graded soils encompassing a broad range of liquid (LL) and plastic limits (PL) are selected and conventional consolidation tests are conducted on these samples. The samples are tested using their natural water content. It was observed that increasing liquid limit and plasticity index decreases $\mathrm{C}_{\mathrm{v}}$.
\end{abstract}

Keywords: Consolidation Coefficient, Liquid Limit, Plastic Index, Consolidation test, Fine-Graded soils 


\section{INCE-DANELİ ZEMINLERIN KONSOLIDASYON KATSAYISI İLE PLASTISITE INNDEKSİ ARASINDAKI ILIŞKININI İNCELENMESI}

\section{ÖZ}

Oturma hesaplanmasında konsolidasyon katsayısı $\left(\mathrm{C}_{\mathrm{v}}\right)$ en önemli parametrelerden biridir. Bu parametre tek boyutlu konsolidasyon testi kullanılarak belirlenebilir. Farklı Likit Limitli (LL) ve Plastisite İndeksli (PI) ince-daneli zeminlerde $\mathrm{C}_{\mathrm{v}}$ 'nin tahmin edilmesi, toprak davranışının daha iyi anlaşılması için önemlidir. $\mathrm{Bu}$ çalışmada, geniş bir aralıkta Likit ve Plastik limitleri (PL) içeren iki iyiderecelenmiş zemin seçilmiş ve bu numuneler üzerinde geleneksel konsolidasyon testleri yapılmıştır. Numuneler doğal su içeriği kullanılarak test edilir. Artan Likit Limit ve Plastisite indeksi, $\mathrm{C}_{\mathrm{v}}$ değerini düşürür.

Anahtar Kelimeler: Konsolidasyon Katsaylsl, Likit Limit, Plastik İndeksi, Konsolidasyon Testi, Ince-Daneli Zeminler

\section{INTRODUCTION}

Settlement in clay soils, specially in soft soils, is a challenging issue. Construction of any structure on this type of soil can be expensive and time consuming. In order to overcome this problem, behavior study of such soils is vital and helps to implement a suitable soil improvement technique. The consolidation process is a mixture of two parameters: the permeability, which controls the rate of the expelling water out of the soil and consequently the rate of settlement at the desired time, and the compressibility, which controls the process of excess pore pressures and thus the duration of the consolidation. During the consolidation process of a saturated clay layer, compressibility and permeability are closely linked together. In the base form of Terzaghi theory in which a linear stress-strain relation and a constant permeability are assumed, the consolidation is controlled by the coefficient of consolidation $\left(\mathrm{C}_{\mathrm{v}}\right)$ (Leroueil, 1987). The coefficient of consolidation demonstrates 1-D consolidation of a clay subjected to a surcharge which is a function of hydraulic conductivity $(\mathrm{k})$, coefficient of compressibility $\left(\mathrm{m}_{\mathrm{v}}\right)$ and unit weight of water $\left(\gamma_{\mathrm{w}}\right)$. This factor can be expressed in the form of

$C_{v}=\frac{k}{\gamma_{w} m_{v}}$

The one-dimensional consolidation test was first suggested by Terzaghi. This test is performed in an oedometer (Das, 2009). Two main standard methods are proposed for evaluating coefficients of consolidation of clayey soils in soil mechanics and foundation engineering applications, namely the logarithm of time fitting (Casagrande method) and the square root of time fitting method 
(Taylor method). Both of these methods need the reading of compression dial gauges at specified intervals of time during the process of consolidation of a clayey specimen in the oedometer under an applied pressure (Taylor, 1948; Lambe and Whitman, 1969; Das, 2009). In the logarithm of time fitting method, $\mathrm{C}_{\mathrm{v}}$ is determined using readings from minimum 24 hours. In this method, $\mathrm{C}_{\mathrm{v}}$ is determined using formula (2) such as:

$C_{v}=\frac{0.197 H^{2}}{t_{50}}$

In which $t_{50}$ is the time required for $50 \%$ consolidation and $\mathrm{H}$ is the thickness of the soil layer. In the square root of time fitting method, readings of the dial gage are taken till the minimum $90 \%$ of the primary compression of the test specimen. In this method, $\mathrm{C}_{\mathrm{v}}$ is calculated using formula (3) as:

$C_{v}=\frac{0.848 H^{2}}{t_{90}}$

In this formula, which $\mathrm{t}_{90}$ is the time required for $90 \%$ consolidation and $\mathrm{H}$ is the thickness of the soil layer. The graphical description of both mentioned methods are shown in figure (1).

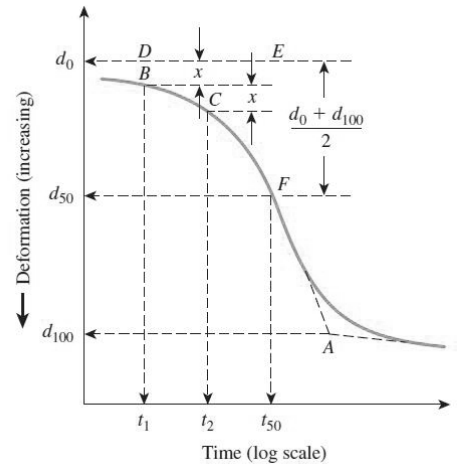

(a)

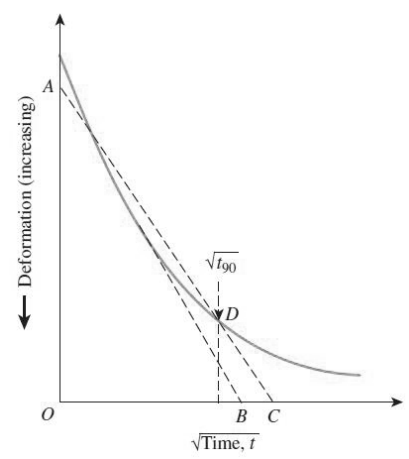

(b) 
Figure 1. (a) Logarithm-of-time method for determining coefficient of consolidation, (b) Square-root-of-time fitting method (Das, 2009).

Due to complexity of these methods, during past decades, researchers have investigated simpler and more reliable methods for the determination of coefficient of consolidation (Naylor and Doran, 1948; Sivaram and Swamee, 1977; Parkin, 1978,1981; Sridharan and Rao, 1981; Mikasa and Takada, 1986; Pandian et al., 1994; Singh, 2005). Although these alternative methods are not used in routine applications as observed from the recommendations of standards on consolidation tests (ASTM D 2435-04), because of the crucial importance of consolidation specially in foundation, prediction and interpretation of the settlement results under different surcharges is necessary. In literature, researchers have focused on the parameters affecting $\mathrm{C}_{\mathrm{v}}$ such as permeability, compressibility, Liquid Limit (LL) and Plastic Limit (PL) of soils. Atterberg limit tests are widely used to measure plasticity of soils (Bekker 1981). In these tests, liquid limit is a limit in which soil initiates to flow and plastic limit depicts the minimum water content to make the soil plastic (Whyte 1982, Haigh et al. 2013). These two parameters are used to calculate plastic index (PI). Due to complexity and long duration of consolidation test, several empirical relations are proposed between Atterberg limits and $\mathrm{C}_{\mathrm{v}}$ (Carrier 1985, Raju et al. 1995, Sridharan and Nagaraj 2004, Asma et al. 2011, Solanki 2011, Devi et al., 2015). Most of these relationships are not applicable for all soil types. Several correlations between these parameters and $\mathrm{C}_{\mathrm{v}}$ have been proposed (Carrier 1985, Raju et al. 1995, Sridharan \&Nagaraj 2004). Carrier (1985) related $\mathrm{C}_{\mathrm{v}}$ with activity (ACT), LL and PL. According to his findings, $\mathrm{C}_{\mathrm{v}}$ is inversely proportioned to Plastic Index (PI). Raju et al. (1995) related $\mathrm{C}_{\mathrm{v}}$ to the void ratio at the liquid limit and the in situ effective overburden pressure for normally consolidated clays. The proposed relationship has some deficiencies due to the limited range of LL and PL. Moreover, the considered consolidation parameter is only related to the LL. Lambe and Whitman (1979) proposed a range for $\mathrm{C}_{\mathrm{v}}$ as shown in Table 1.

Table 1: Typical values for Coefficient of Consolidation.

\begin{tabular}{|l|l|l|l|}
\hline Liquid Limit & $\begin{array}{l}\text { Lower Limit for } \\
\text { Recompression }\left(\mathrm{m}^{2} / \mathrm{s}\right)\end{array}$ & $\begin{array}{l}\text { Undisturbed Virgin } \\
\text { Compression }\left(\mathrm{m}^{2} / \mathrm{s}\right)\end{array}$ & $\begin{array}{l}\text { Upper Limit } \\
\text { Remolded }\left(\mathrm{m}^{2} / \mathrm{s}\right)\end{array}$ \\
\hline 30 & $3.5 \times 10^{-6}$ & $5 \times 10^{-7}$ & $1.2 \times 10^{-7}$ \\
\hline 60 & $3.5 \times 10^{-7}$ & $1 \times 10^{-7}$ & $3 \times 10^{-8}$ \\
\hline 100 & $4 \times 10^{-8}$ & $2 \times 10^{-8}$ & $1 \times 10^{-8}$ \\
\hline
\end{tabular}


Later Sridharan and Nagaraj (2004) proposed a relationship between $\mathrm{C}_{\mathrm{v}}$ and Shrinkage Index (SI). Terzaghi and Peck (1967) mentioned that consolidation coefficient does not change over a wide range of effective vertical consolidation pressure $\left(\sigma_{v}{ }_{v}\right)$. Robinson and Allam (1998) showed the relationship between $\mathrm{C}_{\mathrm{v}}$ $-\sigma^{*}$ and clay mineralogy. Sridharan and Nagaraj (2004) considered the relation of $\mathrm{C}_{\mathrm{v}}$ and $\sigma_{\mathrm{v}}{ }_{\mathrm{v}}$ for different plasticity and same LL which are only valid for remolded soils. Asmar et.al. (2011) correlated coefficient of consolidation with liquid limit for undisturbed silty clay of certain parts of Iraq.

In the absence of reliable correlations, inspection of variation of PI and $\mathrm{C}_{\mathrm{v}}$ seems inevitable to have a better understanding of the estimated results. In this paper, clay and silt samples from various locations with a broad range of PL and LL are selected and their correlation with $\mathrm{C}_{\mathrm{v}}$ is investigated.

\section{MATERIALS AND METHODOLOGY}

In this study, two types of fine- graded soil samples from different districts were used. For the first sample which is named as A1, fine-graded soil percentage was determined as 95.10 after sieve analysis. The second sample, named A2, had 95.52 percent fine-graded materials. The tests were performed according to Turkish Standards (TS-1900). The color of the A1 sample was greenish gray and A2 was red. Specific gravity tests of A1 was achieved as 2.77 and for A2 as 2.74. In the next step, standard Proctor test was performed according to TS 19001. A1 showed maximum dry density $\left(\gamma_{\text {dmax }}\right)$ of $1.570 \mathrm{gr} / \mathrm{cm}^{3}$ at optimum water content $\left(\omega_{\text {opt }}\right)$ of $18.8 \%$. A2 gained its maximum dry density of $1.620 \mathrm{gr} / \mathrm{cm}^{3}$ at $19.6 \%$ optimum water content. In order to classify the soil samples, Atterberg limit tests were done on these samples. In A1, LL was equal to 62.32 and PL is 29.33 , therefore plasticity index was calculated as 32.99 . For A2 sample, LL was obtained as 39.80 and PL as 27, hence PI was obtained as 12.80. Considering USCS classification system (Das B.M, 2009), A1 soil type was determined as high plastic clay $(\mathrm{CH})$ and $\mathrm{A} 2$ soil type as low plastic silt (ML). Figure 2 depicts the tests performed on soil samples. Afterwards, standard Proctor test was performed to find the optimum water content and maximum dry density. 


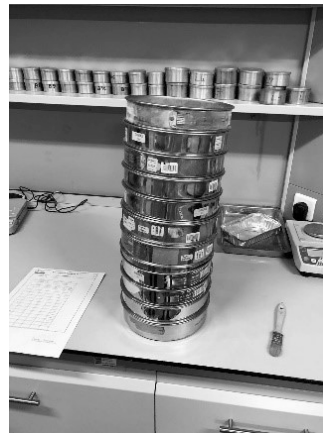

(a)

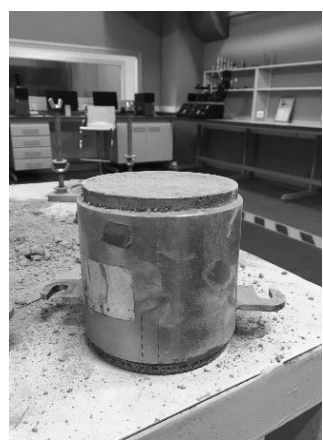

(c)

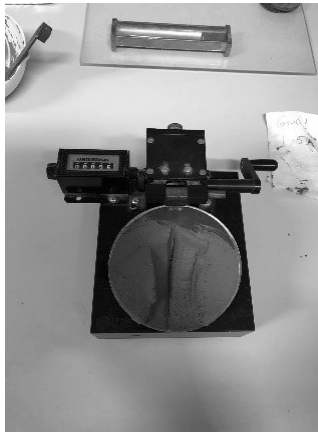

(b)

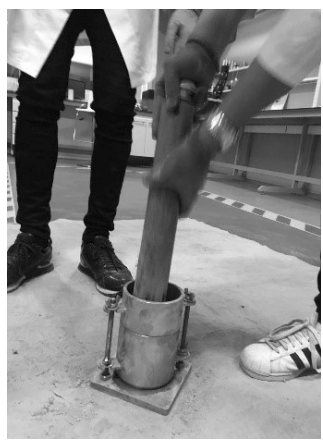

(d)

Figure 2. (a) Sieve analysis, (b) Atterberg test, (c) and (d) Proctor tests performed on soil samples.

Finally, one-dimensional consolidation tests were performed according to TS $1900-2$ standard. The test was conducted with 12,$5 ; 25 ; 50 ; 100 ; 200 ; 400 ; 800 ; 1600$ and $3200 \mathrm{kPa}$ applied stress. Readings were taken using a time interval of 0 , $6,18,30$ seconds and $1,2.25,4,6.25,9,16,25,36,49,64,81,100,121$ minutes and 4,9 and 24 hours. Then, each specimen was unloaded with the ratio of onefourth. Using Taylor's method (Shukla et al. 2009), coefficient of consolidation was calculated. The 1-D consolidation test is shown in Figure 3. 


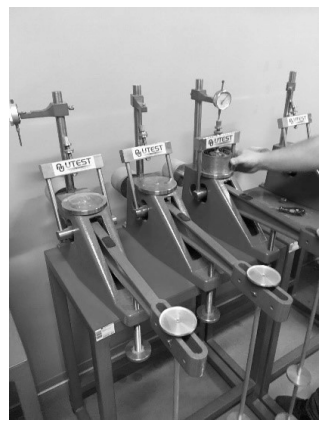

(a)

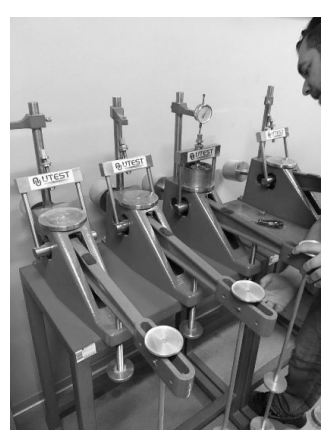

(b)

Figure 3. (a) and (b) Performed consolidation tests.

\section{RESULTS AND DISCUSSION}

Following the steps and tests described in materials and methods, $\mathrm{C}_{\mathrm{v}}$ was determined as $0.87 \times 10^{-3} \mathrm{~cm}^{2} / \mathrm{s}$ for sample A1 and $1.58 \times 10^{-3} \mathrm{~cm}^{2} / \mathrm{s}$ for sample A2. Both samples are classified as fine-graded soils. The specific gravity of both samples are close to each other. According to USCS classification system, LL with higher than 50 are classified as high plastic fine-graded soil and less than 50 is classified as low-plastic soil sample (Das, 2009). According to Ts-1500, both samples are in consistent with USCS and A1 and A2 are classified as high and low plastic soils respectively. Considering these classifications, A1 is classified as high-plastic clay (CH) and A2 is classified as low-plastic silt (ML). Different types of soils are selected deliberately to show the accuracy of the findings which are to correlate the plasticity and liquidity specifications of fine-graded soils with $\mathrm{C}_{\mathrm{v}}$. The summary of the achieved results is presented in Tables 2 and 3 . Considering the findings, it can be concluded that $\mathrm{C}_{\mathrm{v}}$ is not related to plastic limit. Since PL is approximately in the same range for both samples, it was observed that $\mathrm{C}_{\mathrm{v}}$ changes are almost close to PL. Moreover, as the optimum water content and maximum dry weight of two samples were close to each other, the relation between these parameters and consolidation coefficient was not observed.

Table 2: Soil properties of samples.

\begin{tabular}{|l|l|l|l|l|l|l|}
\hline Sample No & Fine-Graded Percentage & $\mathrm{G}_{\mathrm{s}}$ & LL & PL & PI & Soil Type \\
\hline A1 & 95.10 & 2.77 & 62.32 & 29.33 & 32,99 & $\mathrm{CH}$ \\
\hline A2 & 95.52 & 2.74 & 39.80 & 27 & 12.80 & ML \\
\hline
\end{tabular}


Table3: Consolidation parameters.

\begin{tabular}{|l|l|l|l|}
\hline Sample No & $\gamma_{\text {dmax }}\left(\mathrm{gr} / \mathrm{cm}^{3}\right)$ & $\boldsymbol{\omega}_{\text {opt }}$ & $\mathrm{C}_{\mathrm{V}}\left(\mathrm{cm}^{2} / \mathrm{s}\right)$ \\
\hline A1 & 1.570 & $18.8 \%$ & $0.87 \times 10^{-3}$ \\
\hline A2 & 1.620 & $19.6 \%$ & $1.58 \times 10^{-3}$ \\
\hline
\end{tabular}

\section{CONCLUSION}

In order to have a better understanding of $\mathrm{C}_{\mathrm{v}}$ variance, the properties of samples with different water content, specific gravity, liquid limit, plastic limit, sieve analysis and soil classification, fine graded percentage and consolidation coefficient were tested in this study. The tests were performed according to Turkish standards, TS1900-1 and TS1900-2. The classifications of soil materials were done according to Unified Soil Classification System (USCS), which is a prevalent method for soil classification. This classification enables us to have a better comparison between our finding and the literature. Moreover, it is consistent with TS-1900. Samples were determined as high plastic clay and low plastic silt, which is consistent with the aim of this study. In order to have a rigorous and comprehensive research, both types of fine-graded soil materials; silt and clay comprising vast particle diameters were utilized. A broad range of liquid limits represents the soil from low plasticity to high plasticity. Soil classification according to TS- 1900 varies insignificantly from USCS for fine graded soils. TS-1900 considers fine particles with the liquid limit between 35 and 50 as intermediate plastic particles and lower than 35 as low-plastic particles, while USCS categorizes fine particles with LL lower than 50 as low-plastic fine soils. In both standards, the liquid limit higher than 50 is considered as high-plastic soils. Our A1 sample is classified the same in both systems, while A2 sample is considered as intermediate plastic silt using Ts-1900. This difference does not affect our findings significantly, thus the unified system use was preferred. The samples with high fine-graded percentage was preferred in this study so that the impact of coarse-graded materials on behavior of consolidation coefficient was minimized. Obtained $\mathrm{C}_{\mathrm{v}}$ results in Tables 2 and 3 reveal that as plasticity increases, the consolidation coefficient decreases. This finding is applicable for both silt and clay soil types, which can be justified as the long required period of drainage in high plastic soils. Due to plasticity, these soils have a very slow drainage rate and consolidation settlement occurs very slowly. Moreover, it can be observed that $\mathrm{C}_{\mathrm{v}}$ has an inverse proportion with LL too, which can be justified in the same way. The water absorption capacity of soils with high LL is also high and these kind of soils are not willing to lose water rapidly. Due to low variance of optimum water content, the impact on this parameter on consolidation coefficient was not significant in this study. These findings are prominent and can lead to have a better understanding of fine-graded soil material behavior, especially for the calculation of consolidation settlements. 


\section{REFERENCES}

Asma Y. Al-Tae'e \& Abbas F. Al-Ameri. "Estimation of relation between coefficient of consolidation and liquid limit of Middle and South Iraqi soils", 17 (2): 433-440, 2011.

ASTM D2435 / D2435M - 11. Standard Test Methods for One-Dimensional Consolidation Properties of Soils Using Incremental Loading, ASTM International, United States.

Bekker, P.C.F. "Simple Clay Testing Methods". Ziegelindustrie International, 9 , Bau-Verlag, Wiesbaden, Germany, 494-503, 1981.

Carrier, W. D., III, "Consolidation parameters derived from index tests", Geotechnique, 35(2): 211-213, 1985.

Das, B.M. Principles of Geotechnical Engineering-SI Version, Cengage Learning, 2009.

Devi S.P, Devi K.R., Prasad DSV, Raju P.GVR. "Study on consolidation and correlation with index properties of different soils in Manipur valley", International Journal of Engineering Research and Development, 11(5): 57-63, 2015.

Haigh, S. K., Vandanege, P.J., and Bolton M.D. "The Plastic Limit of Clays", Geotechnique, 63(6): 435-440, 2013.

Lambe, T. W. and Whitman, R. V. Soil Mechanics, John Wiley and Sons, New York, 1979.

Leroueil, S. "Tenth Canadian geotechnical colloquium: recent developments in consolidation of natural clays." Canadian Geotechnical Journal, 25: 85-107, 1987.

Mikasa, M. and Takada, N. "Determination of coefficient of consolidation $\left(C_{v}\right)$ for large strain and variable $C_{v}$ values." Consolidation of Soils: Testing and Evaluation, ASTM STP 892, R.N. Yong and F.C. Townsend, Eds., American Society for Testing and Materials, Philadelphia, 526-547, 1986.

Naylor, A.H. and Doran, I.G. "Precise determination of primary consolidation." Proc. of the 2nd International Conference on Soil Mechanics and Foundation Engineering, Rotterdam, 1: 34-40, 1948.

Pandian, N.S., Sridharan, A. and Kumar, K.S. "Improved velocity method for the determination of coefficient of consolidation." Geotechnical Testing Journal, ASTM, 17(1): 113-118, 1994.

Parkin, A.K. "Coefficient of consolidation by the velocity method." Geotechnique, 28(4): 472-474, 1978. 
Parkin, A.K. "Consolidation analysis by velocity method." Proc., 10th International Conference on Soil Mechanics and Foundation Engineering, Stockholm, 1: 723-726, 1981.

Raju Narasimha, P. S. R., Pandian, N. S., and Nagaraj, T. S. "Analysis and Estimation of Coefficient of Consolidation", Geotechnical Testing Journal, 18(2): 252-258, 1995.

Robinson, R. G. and Allam, M. M., "Effect of Clay Mineralogy on Coefficient of Consolidation," Clays and Clay Minerals, 46(5): 596-600, 1998.

Shukla S.K, Sivakugan N, Das B.M. "Methods for determination of the coefficient of consolidation and field observations of time rate of settlement-an overview", International Journal of Geotechnical Engineering, 3(1): 89-108, 2009.

Singh, S.K. "Estimating consolidation coefficient and final settlement: triangular excess pore-water pressure." Journal of Geotechnical and Geoenvironmental Engineering, ASCE, 131(8): 1050-1055, 2005.

Sivaram, B. and Swamee, P.K. "A computational method for consolidation coefficient." Soils and Foundations, 17(2): 48-52, 1977.

Solanki C. H. "Quick settlement computation of shallow foundation using soil index and plasticity characteristics", Geotechnical conference, 1-5, 2011.

Sridharan, A., Nagaraj, H.B. "Coefficient of consolidation and its correlation with index properties of remolded soils", Geotechnical Testing Journal, 27 (5): 1-6, 2004.

Sridharan, A. and Rao, A. "Rectangular hyperbola fitting method for one dimensional consolidation." Geotechnical Testing Journal, ASTM, 4(4): 161168,1981 .

Taylor, D.W. Fundamentals of Soil Mechanics, John Wiley and Sons, New York, 1948 .

Terzaghi, K. and Peck, R. B. Soil Mechanics in Engineering Practice, John Wiley and Sons, New York, 1967.

Turkish Standard, TS 1900-1, Methods of testing soils for civil engineering purposes in the laboratory - Part 1: Determination of physical properties, Turkish Standard Institute, Ankara, March 2006.

Turkish Standard, TS 1900-2, Methods of testing soils for civil engineering purposes in the laboratory - Part 2: Determination of mechanical properties, Turkish Standard Institute, Ankara, March 2006.

Whyte, I. L, "Soil Plasticity and Strength- A new approach using extrusion", Ground Engineering, 15 (1): 16-24, 1982. 